\title{
More Paternalism in the Regulation of Consumer Financial Investments?: Private Sector Duties and Public Goods Analysis Iris H-Y Chiu*
}

\section{Introduction}

Retail investment in financial products is an important part of ordinary financial life, in order to meet savings needs, especially in the current ultra-low interest rate environment. However, retail investors can be let down in a number of ways. One is mis-selling, such as of unregulated products, as in the case of the collapsed London and Capital Finance (LCF). ${ }^{1}$ Mis-selling can also take place with respect to regulated products, when consumers purchase what is unsuitable for them, advised ${ }^{2}$ or otherwise. ${ }^{3}$ Investors can also be let down by severe losses due to adverse market forces, such as during the onset of the global financial crisis, ${ }^{4}$ or as a result of investment managers' sub-optimal strategies.

The regulatory regime for financial investments has undergone significant reform in the UK, from a self-regulatory and pro-industry state of affairs in the 80 s and $90 \mathrm{~s}^{5}$ to maximally harmonised European regulation from 2004. ${ }^{6}$ Marked development in financial investment regulation ${ }^{7}$ also took place after the global financial crisis. ${ }^{8}$ Financial regulation for consumer protection has been enhanced ${ }^{9}$ over the years, and regulators have responded with precise measures to address problems that have surfaced, for example, reforms

\footnotetext{
*Professor of Corporate Law and Financial Regulation, University College London. I thank Alan Brener for his help in putting together a response to the FCA Consultation on Consumer Investments, on which this paper is based. I also thank two anonymous reviewers for helpful suggestions and comments to amend an earlier version of this paper. All errors and omissions are mine.

1 'London Capital \& Finance: $f 236 m$ firm collapses' (BBC News, 9 March 2019),

https://www.bbc.co.uk/news/uk-england-47454328. The FCA's role was critically investigated in The Rt. Hon. Dame Elizabeth Gloster DBE, Report of the Independent Investigation into the Financial Conduct Authority's Regulation of London Capital \& Finance plc (Dec 2020), https://assets.publishing.service.gov.uk/government/uploads/system/uploads/attachment data/file/945247/ Gloster Report FINAL.pdf.

2 Eg FCA's investigative findings on unsuitable pension transfer advice, 'FCA warned of major scandal as almost 2,000 face suitability probe' (27 Jan 2020), https://citywire.co.uk/wealth-manager/news/fca-warned-of-majorscandal-as-almost-2000-face-suitability-probe/a1317159.

${ }^{3}$ Consumers may make poor investment decisions unadvised, Hooman Estelami, 'Cognitive Drivers of Suboptimal Financial Decisions: Implications for Financial Literacy Campaigns' (2009) 13 Journal of Financial Services Marketing 473.

${ }^{4}$ Eg Dimity Kingsford-Smith, 'Regulating Investment Risk: Individuals and the Global Financial Crisis' (2009) 32 UNSW Law Journal 514.

${ }^{5}$ The regulation of investment markets was largely self-regulatory, led by trade associations until the institution of the Securities Investments Board in 1986, chs 2, 3 Julia Black, Rules and Regulators (Oxford: Clarendon 1993).

${ }^{6}$ Markets in Financial Instruments Directive 2004/39/EC (MiFID 2014).

${ }^{7}$ MiFID (2014) and Markets in Financial Instruments Regulation 600/2014.

${ }^{8}$ Niamh Moloney, 'The Investor Model Underlying the EU's Investor Protection Regime: Consumers or Investors?' (2012) 13 European Business Organisations Law Review 169; Iain Ramsay and Toni Williams, 'Peering Forward, 10 Years After: International Policy and Consumer Credit Regulation' (2020) 43 Journal of Consumer Policy 209.

${ }^{9}$ Although this can be argued to be focused on financial stability concerns, rather than consumer welfare as such.
} 
addressing illiquid investment funds. ${ }^{10}$ The recent LCF scandal has again prompted the FCA to revisit consumer investment regulation. ${ }^{11}$

This article argues that more regulatory intervention in the retail investment market is warranted. Although the FCA seeks input into how existing regulated activities may be improved, suggested improvements are incremental in nature. Further, the FCA is keen to see how the market for consumer investments can be made to work better. It is however queried whether retail investors' demand is for a much higher level of consumer protection, even in the area of discretionary investments, in order to bring about a change in the social contract for investor protection, towards greater pro-sociality and consumer care. The next Section takes stock of the needs in consumer investor protection and identifies gaps that are not optimally catered for by self-care or market-based solutions. These gaps provide a basis for considering a comprehensive agenda for regulatory intervention beyond precise and patchwork measures already carried out. More regulatory intervention into consumer investments, which may be regarded as a discretionary good, can however be regarded as paternalistic. We explore in Section 2 the appropriate type of paternalism for reforming consumer investment regulation. We argue that instead of reliance on market-based regulation or libertarian paternalism which focuses on framing consumers' choice sets, 'impure' paternalism, which Dworkin explains as imposing constraints or obligations on one in order to protect another, ${ }^{12}$ needs to be enhanced. Impure paternalism provides a basis for the assumption of responsibility on the part of others to help 'bridge' investors towards better decision-making, post-sale considerations and ultimately to realise welfare outcomes. This does not mean that private sector providers are asked to bear an inordinate burden, as a balance of assumption of responsibility can be achieved in terms of public goods provision and private sector responsibility. Increased paternalism in the regulation of consumer finance has in general been observed, ${ }^{13}$ and the time has come to refrain from rejecting such regulatory designs in relation to retail investment, in order to meet the objectives of public interest, regulatory optimality and social needs. ${ }^{14}$ Section 3 explores how impure paternalism can give rise to certain reforms in the pre-sale, post-sale and welfare stages of a consumer's investment journey. This Section contains the paper's original proposals for reform. Section 4 concludes.

\section{GAPS IN CONSUMER INVESTOR PROTECTION}

Investors in the retail investment market have chiefly been protected by information disclosure regulation, based on the assumption that a fully-informed rational investor is

\footnotetext{
${ }^{10}$ FCA Policy Statement, https://www.fca.org.uk/publication/policy/ps19-24.pdf, FCA Handbook COBS 5.6.5E.

${ }^{11}$ FCA, Call for Input: Consumer Investments (15 Sep 2020), https://www.fca.org.uk/publications/callsinput/consumer-investments.

12 Gerald Dworkin, 'Paternalism' (1972), Part III, http://web.uncg.edu/dcl/courses/vicecrime/m2/Dworkin Paternalism.html.

13 Section 1.

${ }^{14}$ In this regard we move away from purely economic-based rationales for financial regulation, FCA, Economics for Effective Regulation (2016), https://www.fca.org.uk/publications/occasional-papers/occasional-paper-no13-economics-effective-regulation. Pro-social rationales for financial regulation, Harry McVea, 'Financial Services Regulation Under the Financial Services Authority: A Reassertion of the Market Failure Thesis?' (2005) 64 Journal of Consumer Law Journal 413-448; Tamara Lothian, Law and the Wealth of Nations (NY: Columbia University Press 2016).
} 
best-placed to navigate choice in the marketplace. ${ }^{15}$ Behavioural theories of finance ${ }^{16}$ have now convinced policy-makers that this model of the retail investor ${ }^{17}$ is too idealistic, hence reforms have been introduced, after the global financial crisis, to improve disclosure regulation in relation to short-form documents that are user-friendly, ${ }^{18}$ and the presentation of salient terms to draw investors' attention. ${ }^{19}$ Although disclosure presentation reforms are still subject to critique in terms of being inadequately tested with consumers, ${ }^{20}$ the disclosure regulation remains a fundamental baseline. ${ }^{21}$ The regulation of marketing communications in a manner that would be fair, clear and not misleading ${ }^{22}$ is also a key pillar of investor protection. However, even with improved disclosure formats and presentation, consumers may not attain optimal levels of understanding, such as in relation to financial and contractual terms. ${ }^{23}$

Disclosure regulation is not the only investor protection measure. Where investors seek professional help to navigate investment choice, a provider of advisory services or portfolio

\footnotetext{
15 Diane Bugeja, Reforming Corporate Retail Investor Protection: Regulating to Avert Mis-Selling (Oxford: Hart Publishing, 2019), ch1, 3-12.

${ }^{16}$ Anne-Francoise Lefevre and Michael Chapman, 'Behavioural Economics and Financial Consumer Protection' (OECD Working Paper2017), http://dx.doi.org/10.1787/0c8685b2-en.

${ }^{17}$ Niamh Moloney, How to Protect Investors (Cambridge: CUP 2010), ch1.

18 E.g. the prospectus summary, EU Prospectus Regulation 2017/1129; the Key Investor Document, UCITs Directive 2009/65/EU and Commission Directive 2010/43/EU; Insurance Distribution Directive 2016/97/EU and Pan-European Personal Pension Product Regulation 2019/1238; the Key Investor Information Document, PRIIPs Regulation 1286/2014; and consumer information sheets for consumer and mortgage credit, Consumer Credit Directive 2008/48/EC and Mortgage Credit Directive 2014/17/EU, see Veerle Colaert, 'Product Information for Banking, Investment and Insurance Products' in Veerle Colaert, Danny Busch and Thomas Incalza (eds), European Financial Regulation: Levelling the Cross-sectoral Playing Field (Oxford: Hart 2019), ch13.

The efficacy of short-form documents in improving consumer understanding is found to be mixed, Andrew Godwin and lain Ramsay, 'Short-form Disclosure Documents-An Empirical Survey of Six Jurisdictions' (2016) 11 CMLJ 296; Andreas Oehler, Andreas Höfer and Stefan Wendt, 'Do Key Investor Information Documents Enhance Retail Investors' Understanding of Financial Products? Empirical Evidence' (2014) 22 Journal of Financial Regulation and Compliance 115.

${ }^{19}$ Markets in Financial Instruments Commission Regulation (MiFID Commission Regulation) 2017/565, Arts 4450 providing lists of standardised information to clients. The list approach may promote box-ticking, instead of engaging investors' attention, Brigitte Goulard, Peter Aziz and Matthew Gragtmans, 'Can Disclosure in Canada's Federal Financial Consumer Protection Framework Protect the Digital Consumer?' (2015) 35 BFLR 333, Joseph A Franco, 'A Consumer Protection Approach to Mutual Fund Disclosure and the Limits of Simplification' (2009) 15 Stan JL Bus \& Fin 1.

${ }^{20}$ Board of Governors of the Federal Reserve System, 'Designing Disclosures to Inform Consumer Financial Decision-making: Lessons Learned from Consumer Testing' (Federal Reserve Bulletin, Aug 2011, Issue 3); Talia B Gillis, 'Putting Disclosure to the Test: Toward Better Evidence-Based Policy' (2015) 28 Loy Consumer L Rev 31; Y. Gómez, V. Martínez-Mole's and J. Vila, 'Spanish Regulation for Labeling of Financial Products: A BehavioralExperimental Analysis' (2016) 33 Econ Polit 355 on labelling reforms triggering unintended consequences of obfuscation.

${ }^{21}$ Geraint Howells, 'The Potential and Limits of Consumer Empowerment by Information' (2005) 32 JLS 349.

22 FCA Handbook COBS 4.1, on how manipulative advertising can push the boundaries of 'fair, clear and not misleading', Gavin Brookes \& Kevin Harvey, 'Just Plain Wronga? A Multimodal Critical Analysis of Online Payday Loan Discourse' (2017) 14 Critical Discourse Studies 167.

23 John Y Campbell, 'Restoring Rational Choice: The Challenge of Consumer Financial Regulation' (2016) 106 American Economic Review 1 calling for more paternalistic regulatory measures beyond disclosure.
} 
management is regulated to the standard of suitability ${ }^{24}$ or appropriateness. ${ }^{25}$ These reforms, first introduced in the EU Markets in Financial Instruments Directive (MiFID) in 2004, were seen as gold standards in investor protection harmonised across the EU. However, the duty of suitability for investment advice is circumscribed in a number of ways: first, it applies in full to a retail investor, but is lightly applied if an investor is classified as 'professional', which can be on the basis of knowledge, wealth or experience, ${ }^{26}$ next, it is a duty targeted at the suitability of a product, and need not mean that the adviser has surveyed the market and picked the optimal product for the investor. ${ }^{27}$ An 'independent' adviser who is not tied to particular product providers is under a duty to implement a process to survey the market adequately, ${ }^{28}$ but such a duty is framed procedurally and not substantively, raising questions as to how a challenge for sub-optimal choice may be interpreted in court. Third, until the UK's Retail Distribution Review (RDR), ${ }^{29}$ advisers regularly received product providers' commission as remuneration and this affected the objectivity of their advice. ${ }^{30}$ Although the UK introduced reform to ban advisers from receiving commissions ${ }^{31}$ except in limited circumstances, ${ }^{32}$ this led to changes in the nature of the advice market to investors' disadvantage. The FCA has not fully addressed these unintended adverse consequences.

Retail investors experience gaps in protection in three ways. One relates to point of sale, although regulatory reforms have been targeted at this aspect to combat mis-selling. ${ }^{33}$ Investors need guidance in navigating the market and making a decision at point of sale. This pertains not only to averting mis-selling but also to decision-making for the purposes of financial health. ${ }^{34}$ Such a more holistic view of investor decision-making is not addressed by existing regulation. Indeed, investors' unmet need for help in decision-making has become a persistent gap and it is questionable if this is met by merely increasing information provision in standardised mandatory disclosures of salient terms, ${ }^{35}$ and the production of suitability reports after advice is given. ${ }^{36}$

\footnotetext{
${ }^{24}$ MiFID (2014), Art 25; and Arts 52, 54-55, MiFID Commission Regulation 2017/565; FCA Handbook COBS $9 A .2$ 25 MiFID (2014), Art 25; Arts 52, 55-56, MiFID Commission Regulation 2017/565; FCA Handbook COBS 10.2 for non-MiFID business and 10A.2 for MiFID business.

${ }^{26}$ Art 45, MiFID Commission Regulation 2017/565; FCA Handbook COBS 3.1.4.

${ }^{27}$ Advice can be 'restricted' i.e. the adviser is tied to a limited range of products. The procedural application of suitability can be a formalistic and substantively disengaged exercise, Andreas Oehler and Daniel Kohlert, 'Financial Advice Giving and Taking- Where are the Market's Self-Healing Powers and a Functioning Legal Framework When We Need Them?' (2009) 32 Journal of Consumer Policy 91.

28 MiFID Commission Regulation 2017/565, Art 53(1).

${ }^{29}$ Financial Services Authority, Distribution of Retail Investments: Delivering the RDR - professionalism (2011), https://www.fca.org.uk/publication/policy/fsa-ps11-01.pdf.

${ }^{30}$ A problem widely criticised, see pre-RDR literature, Gerard Spindler, 'Behavioural Finance and Investor Protection Regulations' (2011) 34 Journal of Consumer Policy 315; Roman Inderst and Marco Ottaviani, 'Regulating Financial Advice' (2012) 13 EBOR 337; other jurisdictions: Richard Batten and Gail Pearson, 'Regulating Financial Advice' (2013) 87 St John's Law Review 511.

${ }^{31}$ FCA Handbook COBS 6.1A.

$32 \mathrm{Ibid}$ at COBS 6.1A.1A-2A.

33 Discussed above.

34 John Kozup and Jeanne M Hogarth, 'Financial Literacy, Public Policy and Consumers' self-Protection' (2008)

42 Journal of Consumer Affairs 127.

35 See note 19.

${ }^{36}$ Art 54, MiFID Commission Regulation 2017/565.
} 
Next, retail investors experience a gap in protection in terms of post-sale care. Regulatory attention is currently focused on the sale context. Retail investors may need to review investments in light of changing circumstances or may need guidance in relation to continuing decisions for existing investments, such as to hold or sell when performance disappoints. A periodic review duty is only imposed for portfolio managers, ${ }^{37}$ unless expressly offered. Post-sale care is likely inapplicable to many retail investors who do not commission private wealth management.

Third, retail investors experience a gap in protection in relation to their welfare or outcomes in participating in investment markets. It may be argued that investment welfare outcomes are private goods and cannot be guaranteed by regulation. ${ }^{38}$ However, the purely 'private goods' analysis is misplaced. Retail investors participate in investment markets not only because of discretionary preferences, but because of the drive of socio-economic policy turning them into financial citizens, ${ }^{39}$ being primarily responsible for providing for their own financial welfare in the face of state retreat from welfare provision. Investment can become a necessary channel for young parents saving up for their children's higher education. Investment is the primary way to save for medium to longer term needs in relation to housing and retirement. In this manner, welfare expectations or losses are not merely private problems in terms of luck egalitarianism. Welfare losses or shortfalls can be framed as problems of a social nature in relation to the mass market and citizenly underpinnings ${ }^{40}$ of investment participation. ${ }^{41}$ Indeed, the social nature of investment participation underpins regulatory reforms such as mandatory auto-enrolment into occupational pensions saving schemes, ${ }^{42}$ the public provision of NEST, ${ }^{43}$ as well as tax allowances that incentivise saving. ${ }^{44}$ However, compared to the area of consumer credit where evidencebased narratives of welfare losses ${ }^{45}$ support regulatory interventions, investment services regulation has rarely connected with welfare needs and outcomes. For example, regulatory

\footnotetext{
${ }^{37}$ Art 25(6), MiFID (2014).

38 David Llewellyn, 'Consumer Protection in Retail Investment Services: Protection Against What?' (1994) 3 Journal of Financial Regulation and Compliance 43.

39 Joanna Gray and Jenny Hamilton, Implementing Financial Regulation: Theory and Practice (Chicester: John Wiley \& Sons 2006), ch6.

${ }^{40}$ Sarah Nield, 'Mortgage Market Review: 'Hard-Wired Common Sense?” (2015) 38 Journal of Consumer Policy 139 arguing that post-sale customer care for mortgage credit ought to be based on citizenly values in relation to retail financialisation.

${ }^{41}$ Dimity Kingsford Smith and Olivia Dixon, 'What Next for the Financial Consumer: More Disclosure? Caveat Vendor? FinTech Online?' in Geraint Howells, lain Ramsay and Thomas Wilhelmsson (eds), Handbook of Research in International Consumer Law (Cheltenham: Edward Elgar 2018), ch15.

42 S3, Pensions Act 2008.

${ }^{43}$ National Employment Savings Trust (NEST) accountable to the Department for Work and Pensions and to Parliament.

${ }^{44}$ Individual Savings Accounts Schemes, https://www.gov.uk/individual-savings-accounts.

${ }^{45}$ Abdul Karim Aldohni, 'The UK New Regulatory Framework of High-Cost Short-Term Credit: Is There a Shift Towards a More 'Law and Society' Based Approach?' (2017) 40 Journal of Consumer Policy 321, Andrea Fejős, 'Achieving Safety and Affordability in the UK Payday Loans Market' (2015) 38 Journal of Consumer Policy 181 on the price cap for payday lending. Sumit Agarwal, Souphala Chomsisengphet, Neale Mahoney, Johannes Stroebel, 'Regulating Consumer Financial Products: Evidence from Credit Cards' (2015) Quarterly Journal of Economics 111; Natasha Sarin, 'Making Consumer Finance Work' (2019) 119 Columbia Law Review 1519 on credit card charge limitations under the US CARD Act, regarded as effective for protection from unnecessary welfare losses.
} 
interventions in consumer credit arrangements to cap welfare losses, ${ }^{46}$ or share losses between provider and consumer ${ }^{47}$ do not find similar expressions in the investment services sector. We explore these gaps in turn.

\section{Investor Protection Gap at Point of Sale}

The point of sale gap in investor protection is an 'assistance' or 'advice' gap ${ }^{48}$ as many investors are not helped, and engage in do-it-yourself decision-making that may adversely affect welfare outcomes. ${ }^{49}$ Unhelped consumers risk being mis-sold, and it is arguable that the LCF scandal reflects the adverse consequences of the advice gap. The LCF scandal concerned the marketing of unregulated mini-bonds in unlisted companies but many consumers were unaware of their real nature. Although LCF was regulated for advisory services, the mini-bonds were not sold with advice. In the current low interest rate environment, unadvised retail investors seeking yield had been misled into LCF's risky schemes that were misrepresented. Although the scandal raised a number of issues, such as the FCA's regulatory perimeter and its supervisory approach, ${ }^{50}$ the broader context is the persistent advice gap and hazards for unadvised retail investors. It may be argued that the advice gap is irrelevant as the products were unregulated anyway. This article however points to the LCF scandal as raising two gaps in consumer investment regulation- one is a gap relating to comprehensive product scrutiny which we argue below should be undertaken by the FCA. The other is the gap for facilitating and regulating pre-sale assistance, whose scope would be considerably widened if the FCA also undertakes comprehensive product scrutiny.

The advice gap is an unintended consequence from the FCA's prior reform in the RDR to combat conflicted investment advice. Prior to the RDR reforms, retail investors could be offered apparently 'free' advice by product distributors or investment advisers, as advisers would be remunerated by commissions from product providers. The levels of commission

\footnotetext{
${ }^{46}$ Ibid.

47 Such as the right of borrowers to challenge lenders in an unfair credit relationship, s140A, Consumer Credit Act. Also s75 of the Act allows borrowers to make card companies jointly liable with retailers, see Sarah Brown, 'European Regulation of Consumer Credit: Enhancing Consumer Confidence and Protection from a UK Perspective?'; Karen Fairweather, 'The Development of Responsible Lending in the UK Consumer Credit Regime' in James Devenney and Mel Kenny (eds), Consumer Credit, Debt and Investment in Europe (Cambridge University Press 2012), chs3, 4.

48 The Towers Watson review for the FCA predicted an advice gap for the less affluent, 'Advice Gap Analysis: Report to FCA' (2014), https://www.fca.org.uk/publication/research/advice-gap-analysis-report.pdf; confirmed in HM Treasury and FCA, Financial Advice Market Review (2016).

${ }^{49}$ Empirical findings show that financial advice helps to motivate saving, Fen Liu, Tanzel Yilmazer, Cäzilla Loibl and Catherine Montalto, Professional Financial Advice, Self-Control and Saving Behavior' (2019) 43 International Journal of Consumer Studies 23; also portfolio diversification, which can lead to better investment outcomes than unadvised, Hans-Martin von Gaudecker, 'How Does Household Portfolio Diversification Vary with Financial Literacy and Financial Advice?' (2015) 70 Journal of Finance 489; Cathleen D Zick and Robert N Mayer, 'Evaluating the Impact of Financial Planners' in Olivia S Mitchell and Kent Smetters (eds), The Market for Retirement Financial Advice (Oxford: OUP 2013), ch8.

Such findings are tempered if advisers are affected by conflicts of interest, Roman Inderst and Marco Ottaviani, 'Financial Advice' (2012) 50 Journal of Economic Literature 494; Stephen Foerster, Juhani T. Linnainmaa, Brian T. Melzer, Alessandro Previtero, 'Retail Financial Advice: Does One Size Fit All?' (NBER Working Paper 2014), http://www.nber.org/papers/w20712.

50 Gloster Report (2020).
} 
paid could adversely affect the advisory recommendation. ${ }^{51}$ The tainting of advisory objectivity by commission-fuelled conflicts of interest was perceived as a market failure, hence the UK embarked on radical reform to ban commissions overall, even for restricted advisers tied to certain product ranges. ${ }^{52}$ The European standards in the Markets in Financial Instruments Directive did not take this step, only requiring those advisers who call themselves 'independent' not to receive product provider commissions. ${ }^{53}$ The RDR reforms changed market structures by compelling advisers to set charges up-front with their clients. Advice has now become a service dedicated to clients who are willing to purchase, no longer an ancillary service to purchasing a product. This however explicitly commoditises advice as a distinct investment service and facilitates the building up of a market for advice. The FCA found that this gold-plating measure above the EU standards has priced less affluent customers out of advice ${ }^{54}$ and the quality of advice remains challenging, as only $50 \%$ of reviewed retirement investment advice by the FCA in 2019 were found to be suitable. ${ }^{55}$

The advice gap for many financial consumers who cannot afford advice is a phenomenon unlikely to be resolved by the market. It was envisaged at the point of reform that the commoditisation of advice as a 'premium' product could result in market exclusion. ${ }^{56}$ However, the regulator envisaged that post-reform, independent advice would be distinguished as the premium product from lesser forms of advice, such as 'basic', 'simplified' or 'restricted' advice. A market could be built up for advice meeting different needs at different price levels. ${ }^{57}$ The FCA has attempted to stimulate such market developments with little success. The FCA clarified that advisory duties are triggered upon a 'personal recommendation', ${ }^{58}$ implicitly encouraging product distributors and advisers to 'educate' customers without necessarily triggering the legal risks attached to advisory roles. However, investment firms are risk averse. ${ }^{59}$

The market has not innovated to provide a spectrum of 'advice' or pre-sale assistance catering for the budget-conscious investor. This is partly due to the lack of clarity of the legal risks attached to different degrees of pre-sale engagement. If giving advice attracts the full legal risk of suitability, providers would be incentivised to provide advice at the most comprehensive and expensive level. Further, Ring argues that investors are confused by different labels applied to pre-sale assistance, and so cannot articulate clearly the nature of demand to help shape the market for pre-sale assistance products. ${ }^{60}$ The FCA's review at the end of 2020 reflected that the market has converged upon 'holistic' advice catering for

\footnotetext{
51 Seymour v Ockwell [2005] EWHC 1137 was a case where a handsome undisclosed commission could have affected the investment advice given. The advisor was held in breach of fiduciary duty for failure to disclose the commission.

52 Moloney (2010), ch4.

53 Art 24(7), MiFID (2014).

54 Towers Watson (2014), HM Treasury and FCA, Financial Advice Market Review (2016).

55 Debbie Gupta, 'Improving the suitability of financial advice' (Speech, 12 Sep 2019), https://www.fca.org.uk/news/speeches/improving-suitability-financial-advice.

56 Moloney (2010), ch4.

57 Ibid.

${ }^{58}$ Clarification made after the Financial Advice Market Review, FCA, Perimeter Guidance on Personal Recommendations on Retail Investments (Feb 2018), https://www.fca.org.uk/publication/policy/ps18-03.pdf. 59 FCA, Call for Input (2020), para 3.7.

60 Patrick John Ring, 'Analysing the Reform of the Retail Financial Advice Sector in the United Kingdom from an Agencement and Performativity Perspective' (2015) 19 Competition and Change 390.
} 
relatively wealthy investors, ${ }^{61}$ reinforcing earlier review findings. ${ }^{62}$ Many ordinary investors who may not be able to afford holistic advice, which includes ongoing service and charges, would have to accept a default do-it-yourself position ${ }^{63}$ in navigating a universe of investment product choice, and face product providers' explicit disclaimers of advisory duties in order to access more complex products. ${ }^{64}$

The advice gap is not met by generic advice, although provided by the FCA's Money Advice Service as a public good, ${ }^{65}$ on the basis of the Thoresen review's recommendations. ${ }^{66}$ Generic advice is insufficient to meet consumers' tailored needs, and lacks engagement with the diverse economic and financial challenges for many financial consumers. ${ }^{67}$

Without advisory help, would investors' levels of financial literacy be sufficient to navigate the universe of product choice? Empirical findings of financial literacy levels ${ }^{68}$ in developed countries paint a pessimistic picture, and general financial literacy is arguably too remote to assist investors in particular decisions. ${ }^{69}$ Further, some commentators argue that what is needed for investors is the ability to make predictive performance judgments for credence goods, and this level of financial capability is beyond mere literacy. ${ }^{70}$ Further, financial products have become increasingly complex, ${ }^{71}$ rendering consumer judgment a highly challenging exercise.

${ }^{61}$ FCA, Evaluation of the impact of the Retail Distribution Review and the Financial Advice Market Review (Dec 2020).

62 Europe Economics, Retail Distribution Review: Post-Implementation Review, Report for the FCA (16 Dec 2014).

${ }^{63}$ Early findings on increased levels of customers not being in the market for advice, NMG Consulting, 'Impact of the Retail Distribution Review on Consumer Interaction with the Retail Investments Market' (2014).

${ }^{64}$ Self-help in navigating complex financial products has proved fatal for unsophisticated small businesses in a series of litigation involving interest-rate hedging products, eg Green and another v Royal Bank of Scotland plc (Financial Conduct Authority intervening) [2013] EWCA Civ 1197, Grant Estates Limited (In Liquidation) [2012] CSOH 133; Bugeja (2019); Vincenzo Bavoso, 'Financial Innovation, Derivatives and the UK and US Interest Rate Swap Scandals: Drawing New Boundaries for the Regulation of Financial Innovation' (2016) 7 Global Policy 227.

65 https://www.moneyadviceservice.org.uk/en.

${ }^{66}$ FSA, Thoresen Review of Generic Financial Advice (2008).

67 Asta Zokaityte, 'The UK's Money Advice Service: Edu-Regulating Consumer Decision-Making' (2018) 47

Economic Notes 387.

68 Test-based financial literacy levels can be unstandardised and non-comparable, Oscar A. Stolper and Andreas Walter, 'Financial Literacy, Financial Advice and Financial Behaviour' (2017) 87 Journal of Business Economics 581. A frequent indicator of financial literacy levels is based on the Big Three questions, https://gflec.org/wp-content/uploads/2015/04/3-Questions-Article2.pdf; Leora Klapper and Annamaria Lusardi, 'Financial Literacy and Financial Resilience: Evidence from Around the World' (2020) 49 Financial Management 589.

69 There is an issue of applicational relevance as well as investors losing financial literacy gained over time, Daniel Fernandes, John G. Lynch Jr. and Richard G. Netemeyer, 'Financial Literacy, Financial Education, and Downstream Financial Behaviors' (2014) 60 Management Science 1861; Estelami (2009) on literacy training programmes being less useful as investors rely on behavioural heuristics.

70 Oliver J. Williams, Stephen E. Satchell, 'Social Welfare Issues of Financial Literacy and Their Implications for Regulation' (2011) 40 Journal of Regulatory Economics 1; Victoria Vyvyan, Levon Blue and Mark Brimble, 'Factors that Influence Financial Capability and Effectiveness: Exploring Financial Counsellors' Perspectives' (2014) 8 AABFJ 4.

71 Bugeja (2019); Bavoso (2016). 
The FCA seems to be accepting that pre-sale assistance for investors priced out of the advice market is a necessary good. This is reflected in the FCA's recent consultation on how investment firms may be encouraged to provide 'guidance' without incurring the legal risks of advice. ${ }^{72}$ Such a need is likely to become more pressing as mass retailisation of investments gathers pace with access to digital platforms. ${ }^{73}$ The RDR, though wellintentioned, has created a niche market for advice and perpetuated a market failure for access to pre-sale assistance, which we argue needs to be addressed with proposals in Section 3.

\section{Investor Protection Gap in relation to Post-sale Care}

Other than in portfolio management or as expressly offered by investment advisers, there is no duty of periodic review imposed on investment firms for their retail clients. ${ }^{74}$ This is arguably sub-optimal as many retail investors are not private wealth clients able to commission a portfolio to receive ongoing holistic advice. A retail investor who has been advised to purchase a particular investment product is not only a 'consumer' at the point of sale, but holds a credence good whose welfare effects would only be revealed in due course. It is conceivable that the investor may need assistance to make continuing decisions about the credence good. Continuing decisions have a profound impact on future financial welfare beyond the point of sale. Financial customers, whether advised initially or not, may not enjoy post-sale care. Without any responsibility for continuing post-sale care, investment advisers could be incentivised to consider suitability only at point of sale, with weak interest in customers' long-term needs. ${ }^{75}$ The quality of advice can be affected by the near-term framing of the advisory duty.

Online access to investing may exacerbate the issue regarding lack of post-sale care as digitalisation could cater for immediate gratification and dissociate from meeting customers' continuing needs. ${ }^{76}$ Although online access to digital platforms for retail investment may be welcome for ease of access and cost-effectiveness, ${ }^{77}$ such a selling interface, coupled with the use of automated advice, ${ }^{78}$ can be framed in a manner that emphasises self-care and consumption choice for investors.

Commentators have suggested that a financial product's performance in the medium to long term should determine a financial adviser's remuneration, so that advisers are

\footnotetext{
72 FCA, Call for Input (2020).

73 See discussion below.

${ }^{74}$ Art 25(6), MiFID (2014).

75 Lorna Fox O'Mahony and Louise Overton, 'Financial Advice, Differentiated Consumers, and the Regulation of Equity-release Transactions' (2014) 41 JLS 446, finding that more knowledgeable customers benefit from advice, and there may be a persistent 'assistance' gap for less capacitated customers despite mandatory advice.

76 Tatiana Nikiforova, 'The Place of Robo-Advisors in the UK Independent Financial Advice Market: Substitute or Complement?' (2017) at http://ssrn.com/abstract=3084609.

${ }_{77}$ Growing popularity of digital investment platforms and robo-advice, Public Attitudes to Financial Advice Survey (2016), https://bandce.co.uk/wp-content/uploads/2016/02/201602-Public-attitudes-to-advice.pdf; Facundo Abraham, Sergio L Schmukler and José Tessada, 'Robo-Advisors: Investing through Machines' (World Bank Research and Policy Brief 2019).

78 the largest robo-adviser Nutmeg in the UK has over $£ 800 \mathrm{~m}$ in assets under management but is a restricted adviser recommending its own products.
} 
incentivised to consider the long-term performance of the credence good. ${ }^{79}$ Moving along the paternalism spectrum, ${ }^{80}$ it is also possible to make a case for loss-sharing for credence goods on the basis of advice that fails to take into account of longer term considerations. Post-sale care has been the subject of more paternalistic regulatory interventions in consumer credit. For example, a mortgagee is under a duty to exhaust all workout options before foreclosure can be contemplated, ${ }^{81}$ reflecting regulatory intervention into consumer credit arrangements for the protection of household mortgagors. It can be argued that the credence good nature of investments forms the basis for a relational treatment of investment advisory relations, ${ }^{82}$ warranting regulatory intervention into providing post-sale care. This is further fleshed out in Section 3.

\section{Investor Protection Gap in relation to Welfare Consequences}

Regulatory protection against mis-selling, scams or frauds has always been a cornerstone of financial regulation, as these are likely to result in harm or negative welfare. Ex ante protections include improved mandatory disclosure and communications, and advisory duties discussed above, while ex post measures include enforcement and redress options including regulator-mandated collective redress, ${ }^{83}$ and out-of-court dispute resolution schemes such as the Financial Ombudsman scheme ${ }^{84}$ for retail and small business complainants. It is also a regulatory requirement that firms have robust complaint-handling regimes to deal with customers before issues are externalised. ${ }^{85}$ We argue that ex ante regimes can do more to prevent welfare losses for financial consumers. There is a serious question in the LCF case in relation to blatantly misleading classification of their mini-bond products as eligible for ISAs. If a product approval process is in place, ${ }^{86}$ such a scam may have been deterred. For retail investors who have lost significant sums, it is arguable that prevention is better than cure.

There are also gaps in relation to ex post redress. The Financial Ombudsman's compensation limits are capped at $£ 355,000$ for complaints referred after 1 April 2020 for conduct occurring after 1 April 2019, and at lower amounts for conduct occurring in periods before 1 April 2019. ${ }^{87}$ Private litigation is available to private persons alleging a breach of firms' statutory duties but not available to corporate persons. ${ }^{88}$

\footnotetext{
79 Inderst and Ottaviani, 'Regulating Financial Advice' (2012).

80 Section 2.

81 John Y. Campbell, Howell E. Jackson, Brigitte C. Madrian, and Peter Tufano, 'Consumer Financial Protection' (2011) 25 Journal of Economic Perspectives 91; FCA Handbook MCOB 13.3.2A.

82 Sarah A Holden, 'When, Why, and How Do Mutual Fund Investors Use Financial Advisers?' in Mitchell and Smetters (eds, 2013), ch12; Toni Williams, 'Who Wants to Watch - A Comment on the New International Paradigm of Financial Consumer Market Regulation' (2013) 36 Seattle U L Rev 1217.

83 S404, Financial Services and Markets Act 2000.

${ }^{84}$ S235ff, ibid; Vicki Waye and Vince Morabito, 'Collective Forms of Consumer Redress: Financial Ombudsman Service Case Study' (2012) 12 JCLS 1.

${ }^{85}$ FCA Handbook DISP 1, DISP 1.4. Special rules for problem areas of product mis-selling such as endowment mortgages and personal protection insurance have been instituted, DISP Appendix 1 and 3 respectively.

86 Section 3.

87 https://www.financial-ombudsman.org.uk/consumers/expect/compensation.

88 S137D, Financial Services and Markets Act 2000, MTR Bailey Trading Ltd and another v Barclays Bank plc [2015] EWCA Civ 667.
} 
Besides mis-selling, frauds or scams conducted from the outset to bring about adverse consequences for financial customers, there is also the issue of welfare consequences from sub-optimal investment performance. It may be argued that sub-optimal performance can only lie where it falls, a result of market outworking beyond the control of financial services providers. It may also be argued that investment contracts should not be re-opened after sale in order to seek redistributive welfare consequences for investors. ${ }^{89}$ However, there seems to be an imbalance not only in welfare but also in justice between investors and their financial services providers. Investors may suffer significant personal welfare losses such as old-age poverty, but financial services firms would have benefited from advisory fees, investment management fees and other benefits throughout the duration of the product's maturity. ${ }^{90}$ The short-dated and limited scope of responsibility for financial services providers may be legal but questionable. This point was raised by Moloney a decade ago ${ }^{91}$ arguing that in an age of mass consumption of investment services, investor protection must include policy thinking in terms of how investors should navigate continuing market risks. Leaving each investor to his/her own fortunes is not socially acceptable due to the expertise asymmetries and complexities in managing investments. The materialisation of market risk for investors at scale poses a social problem. This also relates to the lack of postsale care discussed above. In a context where ordinary financial citizens are participating in investment markets in order to secure important financial welfare, the disappointment of the credence good can have adverse social consequences. In light of Dame Gloster's critique against the FCA, ${ }^{92}$ urging a 'more holistic' approach to consumer protection, it is arguable that the FCA's attention needs to be turned increasingly to look upon welfare consequences for consumers, and not merely at procedural issues such as access to market choice, and the tools for navigating choice.

It is arguable that welfare outcomes are not completely ignored as the FCA has made special provision for vulnerable financial customers. 'Vulnerability' is in particular defined as susceptibility to increased risk of harm or detriment. ${ }^{93}$ ' $\mathrm{Harm}$ ' is defined relatively narrowly, in relation to loss or detriment caused by mis-selling, scams or frauds. This may not include wider notions such as unmet welfare outcomes. Nevertheless the latter can be debilitating for an individual's plans, progress and even basic living. Regulatory steer on vulnerability is focused on characteristics such as mental or physical infirmity, stage of life upheaval, low personal resilience and low financial capability, ${ }^{94}$ arguably a narrower set of vulnerability characteristics than identified in Cartwright's taxonomy, which extends to contextual circumstances such as family situations and industry structures that are disadvantageous to financial customers. ${ }^{95}$

\footnotetext{
89 Emmanuel Voyiakis, 'Unconscionability and the Value of Choice' in Mel Kenney, James Devenney and Lorna Fox-Mahony (eds), Unconscionability in European Private Financial Transactions (Cambridge: CUP 2010), ch5.

90 Such as fund management charges, trading charges etc.

91 Niamh Moloney, 'Regulating the Retail Markets: Law, Policy, and the Financial Crisis' (2010) 63 Current Legal Problems 375.

92 Gloster report (2020).

${ }^{93}$ FCA, Finalised Guidance for Firms on the Fair Treatment of Vulnerable Customers (Feb 2021), https://www.fca.org.uk/publication/finalised-guidance/fg21-1.pdf, p9.

94 lbid.

95 Peter Cartwright, 'Understanding and Protecting Vulnerable Financial Consumers' (2015) 38 Journal of Consumer Policy 119; Abdul Karim Aldohni, 'Loan Sharks v. Short-term Lenders: How Do the Law and
} 
Further, it can also be argued that 'vulnerability' has been developed largely to respond to prevention of harm in consumer credit, ${ }^{96}$ and is not stretched sufficiently to encompass investment contexts. For example, if a customer seeks an investment product to protect dependants, then the failure of investment performance can adversely harm provision which could be essential in nature. The context of dependency and the likely adversity to dependants should be a relevant consideration of vulnerability. It can be argued that investors' personal circumstances that indicate key or exclusive reliance on the investment performance of a product for future financial provision makes the investor vulnerable, as the risk of under or non-performance can create significant welfare loss. Commentators support the view that many ordinary citizens can be prejudiced in different ways by the adverse outcome of a financial product, and are vulnerable in a variety of different ways. ${ }^{97}$

In early 2021, the regulator has found that almost 28 million adults in the UK in its Financial Lives Survey can be regarded as 'vulnerable' in the wake of financial challenges entailing from the Covid-19 pandemic. ${ }^{98}$ The high proportion of vulnerable adults spurred the FCA into developing more general guidance for investment firms dealing with vulnerable customers. ${ }^{99}$ Such a guidance shows that firms cannot treat vulnerability assessments as limited to consumer credit. ${ }^{100}$ However, it is still clear from the guidance that considerations of customers' welfare outcomes are limited to preventing harm and detriment at point of sale only, focussing on the preventing of mis-selling. ${ }^{101}$ The FCA identified 'harms and detriments' in relation to point-of-sale weaknesses such as impairment to decision-making, and we observe that the guidance still does not address investors' post-sale concerns relating to investment outcomes and financial welfare. Although a broad legalisation of 'vulnerability' assessment may go some way towards addressing consumer harms, this is still arguably focused on point of sale and does not radically address post-sale welfare consequences.

However, can it be argued that, if regulators intervene in issues of ex post loss and risk distribution in investment product performance, such is tantamount to compelling financial services providers to guarantee outcomes for customers? This is inconsistent with a partial intermediation model of financial services where customers bear capital risks, which also underlies the difference between bank and investment firm regulation. Further, product

Regulators Draw the Line?' (2014) 40 JLS 420 on supply vulnerability describing the lack of choice in markets as affecting consumers' decision-making.

96 Louise Overton and Lorna Fox O'Mahony, 'Stakeholder Conceptions of Later-Life Consumer Vulnerability in the Financial Services Industry: Beyond Financial Capability?' (2018) 41 Journal of Consumer Policy 273, in relation to equity release mortgages, Financial Stability Board, Consumer Finance Protection with Particular Focus on Credit (2011), http://www.fsb.org/wp-content/uploads/r 111026a.pdf.

97 Wider 'vulnerability' assessment seems supported in Jeannie Marie Paterson \& Gerard Brody, "'Safety Net" Consumer Protection: Using Prohibitions on Unfair and Unconscionable Conduct to Respond to Predatory Business Models' (2015) 38 Journal of Consumer Policy 331.

98 FCA, 'FCA finds the Covid-19 pandemic leaves over a quarter of UK adults with low financial resilience' (11 Feb 2021), https://www.fca.org.uk/news/press-releases/fca-finds-covid-19-pandemic-leaves-over-quarter-ukadults-low-financial-resilience.

${ }^{99}$ FCA, Finalised Guidance for Firms on the Fair Treatment of Vulnerable Customers (2021).

${ }^{100}$ Eg FCA Handbook MCOB 3A.8.4 on sale and lease-back credit arrangements; 4.7A on advised mortgage sales, FCA Handbook CONC 5.2A.22 when assessing creditworthiness in consumer credit arrangements. ${ }^{101}$ FCA, Finalised Guidance for Firms on the Fair Treatment of Vulnerable Customers (2021), para 2.19. 
providers could be disincentivised from innovation, ${ }^{102}$ resulting in a stifling and underperforming array of 'safe' products with low risk and low return. Our reform proposals do not amount to such shifts of regulatory burdens. The next Section explains the nature of paternalism underpinning our reform proposals, and Section 3 proceeds to show how increased paternalism can be worked out in meeting retail investors' needs at pre-sale, post-sale and outcomes stages of the investment journey. This Section also shows how the division of labour between public and private goods can be achieved, while securing for investors a more robust investment engagement that is relational and distributively more promising.

\section{INCREASED PATERNALISM FOR CONSUMER INVESTMENT REGULATION}

Paternalism is usually regarded as an external intervention upon an individual's will in order to restrain or to direct such will towards 'what may be good for oneself' ${ }^{103}$ In consumer investments, it may be appropriate for the state or regulator to prescribe avenues of investment in order to meet citizens' financial welfare needs, such as mandatory enrolment into occupational pension schemes. ${ }^{104}$ Such paternalism operates at a level that usually pertains to staple necessary goods and work at the highest common factor amongst citizens. Paternalism can also be manifested in the form of bans against retail participation, such as in products proved to be too risky or adverse. The FCA enjoys powers of product intervention, which allow it to subject the design or marketing of financial products to certain conditions in order to combat the risks they pose to consumer protection and financial stability objectives. ${ }^{105}$ For example, the FCA has exercised such powers against the marketing of binary option products to retail investors, ${ }^{106}$ and the participation by retail investors in all crypto-derivatives and exchange-traded notes. ${ }^{107}$ Further, paternalistic measures such as prescribed investment caps in risky peer-to-peer lending products are designed to limit investors' losses. ${ }^{108}$ These paternalistic instances are however limited and ad hoc in nature. In reforming consumer investment regulation, we argue for a more comprehensive regime that encompasses investors' investment journey, from ex ante to ex post. This involves increased assumptions of responsibilities not only by the regulated industry but also by regulators, in a paradigm of 'impure paternalism'. ${ }^{109}$

The FCA should facilitate and regulate increased pre-sale assistance, post-sale care and scrutinise welfare consequences for consumers in their investment journeys. This is

\footnotetext{
102 the regulation of products may stifle product innovation. But it can also be argued that the incentives of product providers are mis-aligned with investors anyway, Michael Cholbi, 'Paternalism and Duties to Self', Daniel Groll, 'Paternalism and Rights' in Kalle Grill and Jason Hanna (eds), The Routledge Handbook of the Philosophy of Paternalism (Oxford: Routledge 2018), chs 9, 10.

103 Jason Hanna, 'Hard and Soft Paternalism' in Grill and Hanna (eds), The Routledge Handbook of the Philosophy of Paternalism (2018), ch2.

104 S3, Pensions Act 2008.

105 S137D(1)(b), Financial Services and Markets Act 2000.

106 FCA, PS19/11: Product Intervention Measures for Retail Binary Options (29 March 2019), https://www.fca.org.uk/publications/policy-statements/ps19-11-product-intervention-measures-retail-binaryoptions.

107 'FCA bans the sale of crypto-derivatives to retail consumers' (6 Oct 2020),

https://www.fca.org.uk/news/press-releases/fca-bans-sale-crypto-derivatives-retail-consumers.

108 Retail investors cannot invest more than $10 \%$ of their net disposable assets in peer-to-peer loans, FCA

Handbook COBS 4.7.7, 4.7.10.

109 Dworkin (1972).
} 
consistent with the investment good as a credence good, and the FCA's focus on regulatory initiatives at the point-of-sale seems inadequate for consumer investor protection. The FCA's focus on point of sale reflects a bias towards market-based regulation for the financialised citizen, trusting that the right market choice would yield the welfare results hoped for. As explained in the FCA's occasional paper, regulatory interventions in financial markets are 'justified when improvement over the market solution is feasible'. ${ }^{110}$ Hence, the starting point is to allow the market for solutions to first develop. This explains why the FCA remains keen on stimulating the market for pre-sale assistance to address the advice gap highlighted at pre-sale stage. Regulatory or state-backed endeavours are seen as follow-up and proportionately corrective approaches if necessary. Arguably the Markets in Financial Instruments Directive regime is also based on a similar regulatory ideology, ${ }^{111}$ and the investor protection measure of imposing a duty of suitability for advice focuses on the point of sale, reifying the 'optimal' market choice as equivalent to meeting welfare needs. Although there is an overarching 'duty of best interests' ${ }^{112}$ in the MiFID, Busch argues, in our view convincingly, that this is an umbrella 'ethos' whose precise legal content is unpacked in specific investor protection duties such as suitability. ${ }^{113}$ It is not this 'umbrella' framing, but general principles in civil law, ${ }^{114}$ that have given rise to general law protections for financial consumers beyond the MiFID in a number of Continental jurisdictions.

We also argue that contemporary approaches in libertarian paternalism in consumer financial regulation is unlikely sufficient to address the gaps in Section 1. Libertarian paternalism involves framing choice sets for consumers and designing regulatory policy to proactively nudge consumers towards making optimal decisions. ${ }^{115}$ Such paternalism is 'weak' as Sunstein ${ }^{116}$ explains. Libertarian paternalism is market-supporting as it extends into 'making sense' of choices for consumers, but is still based on an operating paradigm that is market-based, i.e. treating as indisputable that market offerings are the starting point for consumer investors' welfare needs. Commentators take the view that 'strong' forms of libertarian paternalism, ${ }^{117}$ such as automatic enrolments or framing of choice sets to target precise choices, are only possible where there is an indisputable standardised good. ${ }^{118}$ In this way, libertarian paternalistic strategies may be relatively rarely employed as they operate on the highest common factor.

\footnotetext{
110 FCA, Economics (2006), p16.

111 Daniel Muggë, 'Resilient Neo-liberalism in European Financial Regulation' in Vivien Schmidt and Mark Thatcher (eds), Resilient Liberalism in Europe's Political Economy (Cambridge: CUP 2014), ch7.

112 Art 24(1).

113 Danny Busch, 'MiFID II: Stricter Conduct of Business Rules for Investment Firms' (2017) 12 CMLJ 340.

${ }^{114}$ Danny Busch, 'The Future of the Special Duty of Care in the Financial Sector - Perspectives from the Netherlands' (2021) 32 European Business Law Review, forthcoming.

115 Cass R Sunstein and Robert H Thaler, Nudge (New Haven, CT: Yale University Press 2008); Cass R Sunstein and Richard H Thaler, 'Libertarian Paternalism is not an Oxymoron' (2003) 70 University of Chicago Law Review 1159.

${ }^{116}$ See Cass R Sunstein, 'Boundedly Rational Borrowing' (2006) 73 University of Chicago Law Review 249.

117 Muireanne Quigley, 'Libertarian Paternalism, Nudging and Public Policy' in Grill and Hanna (eds, 2018), ch18.

${ }^{118}$ Sumit Agarwal, John C Driscoll, Xavier Gabaix and David Laibson, 'The Age of Reason: Financial Decisions over the Life Cycle and Implications for Regulation' (Brookings Institution Working Papers 2009), 51-101.
} 
One example of a weak libertarian paternalistic strategy employed in consumer investments is the framing of 'Simple Products'. ${ }^{119}$ The Treasury commissioned a review into simple financial products so as to steer retail investors towards safe choices, providing a baseline for the unhelped consumer who has savings needs. This may compensate for the unattainability of investment advice. However, the suite of 'simple products' recommended in the Sarjeant review ${ }^{120}$ are unlikely to appeal to retail investors' needs, being bank-based savings products that have become unattractive in the prolonged low interest rate environment. Simple products are inevitably narrow in nature in order to be 'safe', ${ }^{121}$ and although this framing measure was intended to help consumer savers, the limitations of such products have sharpened in current investment market conditions where many retail investors are driven elsewhere to seek yield.

Instead of market-based regulation and relying on selective libertarian paternalism strategies, increased impure paternalism can be introduced to buttress retail investor protection. In such a paradigm, we argue that there should be a greater assumption of duties and responsibilities on the part of the regulated industry and the regulator to address the three gaps discussed in Section 1. Such assumption of duties and responsibilities go further than the current regulatory standards and involve the regulated industry in a longerterm extension of customer care. Further, it also involves the regulator in offering an expanded range of public goods to cater for the consumer investor and to govern the conduct of the regulated industry. The next Section proposes how increased impure paternalism can be realised in consumer investment regulation in the pre-sale, post-sale and welfare stages of the consumer investment journey.

\section{A MORE PATERNALISTIC AGENDA FOR REGULATING INVESTMENT PRODUCTS AND SERVICES}

In analysing the gaps in investor protection in Section 1, it can be argued that we are merely setting out a wish list in order to de-responsibilise investors of their ownership of investment decisions. The 'assistance' gap can be regarded as a need to be hand-held in order to pass the liability for decision-making to the investment adviser, and the gaps for post-sale care and welfare outcomes can be regarded as an excuse to introduce distributive policies in order to guarantee investment outcomes for investors. However, we argue that the gaps above are not merely excuses for paternalistic policy in order to shield investors from the responsibility for self-care. Rather, the ethic of self-care has perhaps been too dominant ${ }^{122}$ in financial regulation. Policy-makers have only gradually responded to demand-side realities in behavioural finance, the lack of financial literacy, ${ }^{123}$ and calls from society to do more in the wake of successive scandals. Financial regulators should appraise

\footnotetext{
119 FCA, Call for Input (2020), para 3.4, Q7.

120 Treasury, Sarjeant Review of Simple Financial Products (2013).

${ }^{121}$ Mervyn K Lewis, 'What Can Be Done About Ponzi Schemes' in Understanding Ponzi Schemes (Cheltenham: Edward Elgar 2016), ch10.

122 Lorna Fox O’Mahony \& Christian Twigg-Flesner \& Folarin Akinbami, 'Conceptualizing the Consumer of Financial Services: A New Approach?' (2015) 38 Journal of Consumer Policy 111; also Sarah Brown, 'Consumer Credit Relationships - Protection, Self-Interest/Reliance and Dilemmas in the Fight Against Unfairness: The Unfair Credit Relationship Test and the Underlying Rationale of Consumer Credit Law' (2016) 36 Legal Studies 230 focused on consumer credit.

123 Mentioned in Moloney (2012).
} 
the gaps highlighted above as opportunities for paradigm shift. It is also not a foregone conclusion that addressing the regulatory gaps highlighted above leads to increased regulatory burdens and cost of compliance for firms, therefore raising the barriers to access for retail investors. What may be missing in analysis so far is that certain gaps may reflect common needs that support the provision of an extent of public goods.

The gaps for investor protection can be analysed in terms of inquiring into the optimal division of responsibility between public and private sector provision. Although in the context of financialisation, all financial citizens, whether sovereigns, corporations or households, ${ }^{124}$ have come to rely on private sector intermediation and services to meet their financial welfare needs, the exclusivity of private sector provision should be queried. ${ }^{125}$ Rethinking the balance of public goods, such as in the introduction of the generic Money Advice Service, is a first and necessary step. It may be argued that public good provision in finance would likely introduce competitive distortions and stifle innovation in financial markets. However that pessimistic conclusion seems premature. Public good provision is also not the same as returning to state welfare. Public and private sector roles can be complementary ${ }^{126}$ and often play out in discourse, coordination and partnerships rather than as binary and unrelated phenomena. We proceed to suggest reform proposals that involve a balance of public and private sector division of responsibility in bridging the gaps discussed.

\section{Proposal for Pre-sale Assistance for Investment Customers}

In relation to the 'assistance' gap at point of sale for investment customers who do not purchase investment advice, there are a few regulatory options that can be considered.

First, we consider mandatory advice, ${ }^{127}$ as a regulatory option, which would be equivalent to increasing the responsibility burden on the part of investment services providers. In this manner, products can only be sold upon advice. Mandatory advice is already required for retail investors in online crowdfunding investments ${ }^{128}$ and equity release mortgages. ${ }^{129}$ However it may be argued that the first is a niche market and investors can weigh the pros and cons of paying for advice and potentially taking advantage of high risk but potentially high return opportunities. The latter is a different market as mandatory advice is instituted on the basis of customer vulnerability and access to advice is made possible by exempting this product from the rules on commission bans. Would mandatory advice for all retail investment products be over-inclusive? Yet if we adopt a much more expansive conception of investor vulnerability, and recognise the significance of each individual coming to a moment of commitment to significant saving, mandatory advice may not be over-inclusive and could be a necessary good. However, making mandatory advice a blanket approach

\footnotetext{
124 Thomas I. Palley, Financialization: The Economics of Finance Capital Domination (London: Palgrave Macmillan 2013).

125 Aldohni (2014), (2017) on consumer credit, Nield (2015) on housing.

126 Julia Black, 'Enrolling Actors in Regulatory Systems: Examples from UK Financial Services Regulation' [2003]

Public Law 63; 'Mapping the Contours of Contemporary Financial Services Regulation' (2002) 2 JCLS 253.

127 Bugeja (2019) only for complex products, ch7.

128 FCA Handbook COBS 4.7.8.

${ }^{129}$ Fox-O'Mahony and Overton (2014).
} 
could mandate more revenues for investment firms in terms of upfront fees from customers, while not necessarily improving the quality of advice. ${ }^{130}$

On the other hand, it can be argued that advisory quality may improve under a mandatory regime as the legal liability entailing from unsuitable advice and the widened channels for retail investor and small business redress through the Ombudsman should incentivise against poor practice. The expansion of the advisory market under a mandatory advice regime may also result in economies of scale for firms and an overall lowering of cost for advice. However, it is uncertain if the cost of mandatory advice would still inhibit the demand side by causing investors to resort to unregulated products and markets, or to ignore the need for saving, which already tends to be ignored due to behavioural biases in favour of procrastination for longer-term needs ${ }^{131}$ and immediate consumption. ${ }^{132}$

Mandatory advice may not be the optimal design in impure paternalism. Unintended consequences may also result from incentives on the part of investment firms.

Nevertheless, there is scope for regulatory measures to incentivise access to advice by lowering cost barriers, for example by providing tax allowances for investment advice expenses, the claims process for which can be made streamlined between the financial sector and HMRC. There is also the possibility of justifying state subsidies for investment advice expenses if advice indeed attains a quality of reliability for investors and becomes an undisputed necessary good.

We propose an alternative to meeting investors' 'assistance gap' by impure paternalistic intervention that divides the burden of responsibility between the public and private sectors. Providing public goods can be relevant in order to deliver a baseline of welfare that is regarded to be necessary. Fundamentally, what is common to investors' needs at point of sale would be clarification, explanation, assistance or 'guidance' ${ }^{133}$ that are not generic but take account of investors' needs, ${ }^{134}$ without necessarily being accompanied by a personal recommendation amounting to advice. Such assistance fulfils both educational and counselling roles, the generic provision of which only produce limited effects for investors. Although it is arguable that pre-sale assistance is more imperative the more complex a financial product is, ${ }^{135}$ this paper argues for a universal baseline of pre-sale assistance for all products. It may be argued that navigating investment could be somewhere between needing to seek specialist advice, such as medical or legal advice and purchasing a generic good in product markets.

\footnotetext{
130 Oehler and Kohlert (2009), also Angela A Hung and Joanne K Yoong, 'Asking for Help: Survey and Experimental Evidence on Financial Advice and Behavior Change' in Mitchell and Smetters (eds, 2013), ch9, arguing that mandatory advice is often ignored.

131 Mike Dixon, Rethinking Financial Capability (2011) at

http://www.ippr.org/files/images/media/files/publication/2011/05/financial_capabilities_1515.pdf.

132 John Gathergood, 'Self-control, Financial Literacy and Consumer Over-Indebtedness' (2012) 33 Journal of

Economic Psychology 590.

${ }^{133}$ Recognised in FCA, Call for Input (2020).

134 Patrick Ring, 'The Regulation and Governance of Financial Advice in Europe: The Implications for the Retail Financial Advice Sector and its Consumers' 99 Governance and Regulations: Contemporary Issues:

Contemporary Studies in Economic and Financial Analysis 33 (Emerald, 2018).

135 Marc-David Weinberger, 'Scope of Protection: Is There a Ground for a Single Criterion?' in Colaert et al (eds, 2019), ch12; Bugeja (2019), ch 7.
} 
The universal baseline of pre-sale assistance should be provided via a combination of private sector responsibility and public goods. The responsibility imposed on the private sector is due to investors' heterogenous individual circumstances, but a necessary complement should be provided as public goods.

First, the investment services provider should be subject to a mandatory duty to provide guidance, to be discharged according to the standard of acting fairly, honestly, and in the best interests of customers, ${ }^{136}$ consistent with the umbrella standard of customer conduct in EU legislation. ${ }^{137}$ This proposed duty exceeds the current MiFID standards as it fills a gap where the advisory context is excluded, hence not attracting the suitability standard, and does not merely default to mandatory pre-sale information disclosure under the MiFID. In this manner, firms assume a new legal duty at the pre-sale stage which cannot be excluded. The standard for discharge, based on the 'umbrella' standard in the MiFID, is less procedural than suitability as applied to advice. This standard would also benefit from development in cases and jurisprudence in due course.

Mandatory pre-sale assistance should be defined offered short of advice. One example of such assistance is the 'demands and needs' analysis that insurance firms have to provide even if not giving advice. ${ }^{138}$ The 'demands and needs' analysis can form a template for providing guidance that is not merely generic but does not amount to making specific recommendations. Such an analysis also goes beyond merely loading mandatory disclosure upon investors.

It may be argued that this new mandatory duty is too onerous for investment services providers. We propose that this duty can give rise to a nominal charge. Further, firms' liability could be statutorily capped if found in breach of the standard of honesty, fairness and best interests, so that a proportionate distributive result can be reached if a dispute rises. The capped liability proposal is made on the basis that investors would still have chosen the investment option and clearly rejected to purchase advice. This provides a balance between retail investors' concern for cost of advice and firms' concern for the clarity of legal risk.

Mandatory pre-sale assistance for investors should be supported by the provision of public goods aimed at enhancing investors' capacity. The Money Advice Service should produce guidance on all types of investment products, from simple to complex, so that a balanced slate of pros and cons can be offered as shorthand pre-sale information to investors. Investors should be made to read, watch a video or hear a podcast of such guidance, as a mandatory requirement before any purchase. ${ }^{139}$ In this manner, the burden of investor

\footnotetext{
${ }^{136}$ Consistent with Art 24(1), MiFID (2014). Paterson and Brody (2015) support the duty as a general 'safety net' for financial consumers, also Hazel Bateman and Geoffrey Kingston, 'Regulating Financial Advice' (2014) 4 JASSA The Fincia Journal of Applied Finance 7.

137 Busch (2017).

${ }^{138}$ Art 20, Insurance Distribution Directive 2016/97/EU, also suggested as a harmonising baseline in EU regulation, see Danny Busch, Veerle Colaert and Geneviēve Helleringer, 'An 'Assist-Your-Customer Obligation' for the Financial Sector?' in Colaert et al (eds, 2019), ch14B.

139 'Just-in-time' financial guidance and warnings seem to be proved useful to investors in empirical surveys, Fernandes et al (2014).
} 
education is shared as provision by public means and by investment services firms. This proposal also compels the Money Advice Service to engage with financial product developments and for the private sector to subject its innovations to a manner of explication and indirect scrutiny. This is not inconsistent with product governance rules under the MiFID, which we shall address shortly.

It may be queried whether it is more optimal for the assistance/advice gap to be met by requiring investors to prove their investment capabilities, such as by having to pass prescribed tests. This is set out in the EU Regulation for Crowdfunding as a measure of investor protection ${ }^{140}$ and also proposed by $\mathrm{Choi}^{141}$ who argues that classifying investors for eligibility in investing would save securities issuers from having to comply with one-size-fitsall rules of comprehensive mandatory disclosure. However, the investor test requirement in the EU regulation can be explained by regarding online crowdfunding investments as niche and non-traditional. Hence investors would have to exert effort to prove eligibility in order to participate. Such an argument holds less well if online crowdfunding investments become mainstream, or are regarded as important for portfolio diversification.

The requirement to prove investor eligibility can produce disincentivising effects upon saving behaviour as investors are likely dissuaded from saving and investing due to the effort required. Fear of investor withdrawal from investment markets could also lead to watering down of prescribed tests, especially if conducted by private sector providers, in order to mitigate the disincentivising effects for investors. ${ }^{142}$ Moreover, it is not easy to design optimal investor tests that assure of necessary financial capability, ${ }^{143}$ and given the uncertain nature of what test results really mean for financial capability, an investor who passes can be falsely assured of her level of competence. An erroneous investment decision made in this manner can lead to welfare losses which would solely be borne by the investor.

On balance, increased impure paternalism for investor protection at point of sale is not optimally designed if the entire burden is merely shifted to investment services providers or to investors. A three-way balance of enhancing proportionate responsibility for guidance, coupled with just-in-time financial education and warnings, where investors have chosen not to be advised, could be the answer to plugging the investor protection gap at point of sale.

\section{Proposal for Post-sale Care for Investors and Welfare Consequences}

In existing legislation, immediate post-sale rights, such as the cooling-off right, is available for distance marketing of financial services ${ }^{144}$ and certain financial products. ${ }^{145}$ Although these address the behavioural problem of impulse decisions ${ }^{146}$ and can mitigate welfare

\footnotetext{
140 Regulation (EU) 2020/1503.

${ }^{141}$ Stephen J Choi, 'Regulating Investors Not Issuers: A Market-Based Proposal' (2000) 88 California Law Review 279.

142 Agarwal et al (2009).

143 Ibid.

${ }^{144}$ Art 6, Distance Marketing of Financial Services Directive 2002/65/EC.

${ }^{145}$ Such as subscription of securities, FCA Handbook PRR 2.2; p2p lending arrangements, CONC 11.2. A

reflection period of 7 days is offered for consumer mortgages, MCOB 6A.3.4.

146 Sunstein (2006); Campbell et al (2011), Cartwright (2015).
} 
adversities, a cooling-off right can also work in a behaviourally sub-optimal manner if investors regret saving and prefer to fund immediate consumption instead. Hence, a cooling-off right should be accompanied by a right to switch so as to encourage investors to save. Further, the Money Advice Service can do more in terms of encouraging precautionary saving on the part of ordinary citizens, in order to improve general financial resilience. ${ }^{147}$

We argue that post-sale care should extend beyond immediate post-sale rights to addressing investors' concerns about ex post performance of the product, and how such performance is related to their financial health needs in due course. For example, an investor in an open-ended mutual fund that suffers loss in the first year may need assistance in deciding whether to hold or to exit. ${ }^{148}$ Such decisions benefit from guidance or advice. It may be rather prescriptive to dictate how firms carry out their relational conduct with investors, but a baseline principle is needed in conceptualising investment relations as not merely transactional but as relational in nature. In this manner, FCA guidelines may urge that best practices be forged around periodic reviewing of performance with investors, and offering of guidance subject to the regulatory proposal for guidance argued above.

Ultimately, point-of-sale or post-sale conduct are not perfect proxy indicators for investors' welfare outcomes in due course. There is inevitably a need to consider how the connection between investors' welfare and the design of investment products can be better ascertained $a b$ initio. As investment products are credence goods, their engineering may not yield as predictable results as physical consumer goods subject to product liability. The EU product governance rules ${ }^{149}$ is a starting point that seek to align product design with demand-side needs. However, more can be done to refine these rules to engage with investors' welfare needs and expectations.

\section{Proposal for Enhanced Product Governance}

The EU's product governance rules apply in a manner that is designed to shape firms' internal decision-making, requiring product manufacturers to consider an appropriate target market and their needs, so that the product's features are suitable for them. Product manufacturers then need to provide comprehensive information to distributors, while distributors should independently ensure that marketing of the product is carried out to a suitable target market. ${ }^{150}$ The MiFID standards in product governance raise two hazards. One is that being tied to suitability, which revolves around risk appetite and customers' current financial health, product governance is insufficiently connected with 'welfare outcomes', i.e. customers' ultimate needs in investment expectations. There is scope for product designers to be required to explain more explicitly how products may meet welfare needs or claims, even if market risk is involved. Second, product governance rules are based on internal regulation of firms' processes, and could result in firms' self-implementation that is insufficiently monitored by the regulator.

\footnotetext{
${ }^{147}$ Christoph Basten, Andreas Fagereng and Kjetil Telle, 'Saving and Portfolio Allocation Before and After Job Loss' (2016) 48 Journal of Money, Credit and Banking 293

148 'Emotions Cost Investors Dear, Research Finds' (Financial Times, 23 Oct 2020).

149 MiFID Commission Directive 2017/593, Arts 9, 10, Antonio Maracci, 'European Regulatory Private Law Going Global? The Case of Product Governance' (2017) 18 EBOR 305.

150 Commission Delegated Directive (EU) 2017/593 of 7 April 2016, arts 9, 10.
} 
The FCA should consider ex ante scrutiny of product governance implementation as provision of a public good that shapes and steers product providers' incentives. This article submits that the FCA's recent guidance ${ }^{151}$ on vulnerable customers, which requires firms to incorporate into their product design and testing processes vulnerability characteristics and their impact on target markets, is still insufficient as the additional requirement does not change from the modus of firm self-implementation under product governance rules. It may be argued that if regulators take on this role, it would be tantamount to certifying products and this may provide a false sense of product guarantee for a credence good. Regulators may not have the expertise to certify products either. However, regulators can take on the role of 'approving' a firm's product governance in giving rise to each product, on the basis of being reasonably convinced that the product manufacturer has delivered substantive justification for the product being developed to meet certain welfare expectations in a suitable target market. In this manner, regulators would offer a limited role of product clearance that is not fully based on merit. Product manufacturers nevertheless are expected to explain in layman terms to the regulator the product features that would deliver certain expected welfare needs, and why such product features are suitable for their target market. Even if regulators' product clearance is limited in nature, this ex ante process of product scrutiny can instil discipline for adhering to product governance standards. This is important as product providers have been prone to designing products in a manner excessively shaped by their own incentives. ${ }^{152}$ Investment firms would be pushed in this manner to internalise the possibilities of long-term welfare consequences for consumers in their product design. Further, we proposed earlier that product manufacturers should also make product explication to the Money Advice Service to enable publicly accessible information and warnings to be formulated 'just-in-time' for investors at pre-sale stage. Regulatory gatekeeping and scrutiny can therefore exist at the levels of the FCA and Money Advice Service.

Ex ante regulatory gatekeeping in product governance can incentivise more considerate product design aligned with securing investors' welfare expectations. Product providers may refrain from unnecessary complexity or opacity which would be scrutinised. Product manufacturers may also engage in socially useful testing exercises before products are finalised and distributed. ${ }^{153}$ Increased and engaged supervision for investment products necessarily expands the FCA's regulatory perimeter which we argue is timely and necessary as maintaining artificial boundaries between regulated and unregulated products has caused confusion, as illustrated by the LCF scandal. It seems retrograde for the FCA to focus on clarifying stakeholders' expectations with regard to the limitations of its regulatory perimeter, ${ }^{154}$ instead of seeking to consider the public good of a more comprehensive product oversight regime. ${ }^{155}$

\footnotetext{
${ }^{151}$ FCA, Finalised Guidance for Firms on the Fair Treatment of Vulnerable Customers (2021), paras 4.5-4.23.

152 Dan Awrey, 'Towards a Supply-Side Theory of Financial Innovation' (2013) 41 Journal of Comparative Economics 401.

${ }^{153}$ Andreas Oehler \& Stefan Wendt, 'Good Consumer Information: the Information Paradigm at its (Dead)

End?’ (2017) 40 Journal of Consumer Policy 179.

154 FCA, Call for Input (2020), Qs 26, 27.

155 Elizabeth Warren, 'Product Safety Regulation as a Model for Financial Services Regulation'(2008) 42 Journal

of Consumer Affairs 452; Eric A. Posner \& E. Glen Weyl, 'An FDA for Financial Innovation: Applying the
} 
It is also arguable that the FCA's engagement with investment product development and innovation can be located at an earlier stage where product manufacturers and the regulator engage in a sandbox for investment products. Sandboxes are used for technologically-powered innovations in particular, ${ }^{156}$ but they can be useful for regulators to engage with innovation in general. ${ }^{157}$ There are hazards however regarding the opacity of regulated-regulators' relations in the sandbox and the need to ensure that regulatory capture is minimised. ${ }^{158}$

\section{Proposal for Ex post Redress Rights}

Next this article also argues that the welfare consequences for investors can be better protected by giving them an ex post right to challenge product manufacturers and distributors for product governance failings in the event of sub-optimal performance affecting financial welfare. Given investors' heterogenous characteristics and needs, ex ante regulatory protections may only provide a standardised baseline, and individual welfare may be more fully pursued if ex post challenge can be framed as investors' rights and can be readily accessible. ${ }^{159}$ In this respect the article echoes previous work on expanding rights to private redress, whether as part of regulatory enforcement, or as stand-alone challenges, and the need to consider an accessible Tribunal that can provide legal clarification and jurisprudence besides dispute resolution before the Ombudsman. ${ }^{160}$ Commentators have also argued for investors to have a right to ask for the reversal of burden of proof so that product manufacturers and distributors should explain how their products have been designed to meet investors' welfare needs. ${ }^{161}$ The article supports this on the basis of the difficulty for investors to gain access to information within firms in relation to product design and governance processes.

In sum, this article argues that more paternalistic protection of the retail investor is warranted and possible. It may not be warranted or practicable for the burden to be wholly shifted to the industry, or to raise the bar for investors given the need to encourage saving and to overcome the barriers to participation. Hence there is room to unpack where public goods may best be supplied to complement an enhanced regime for investor protection.

\footnotetext{
Insurable Interest Doctrine to the Twenty-First-Century Financial Markets' (2012), http:// papers.ssrn.com/sol3/papers.cfm?abstract_id=2010606.

156 Ross P Buckley, Douglas W Arner, Dirk A Zetzsche and Robin Veidt, 'Building FinTech Ecosystems: Regulatory Sandboxes, Innovation Hubs and Beyond' (2020) 61 Washington University Journal of Law and Policy, https://papers.ssrn.com/sol3/papers.cfm?abstract id=3455872; Deidre M Ahern, 'Regulators Nurturing FinTech Innovation: Global Evolution of the Regulatory Sandbox as Opportunity Based Regulation' (2020), https://papers.ssrn.com/sol3/papers.cfm?abstract_id=3552015.

157 Iris H-Y Chiu, 'A Rational Regulatory Strategy for Governing Financial Innovation' (2017) 8 European Journal of Risk Regulation 743.

158 Ibid; also Hilary J Allen, 'Regulatory Sandboxes' (2019) 87 George Washington Law Review.

159 Olha O Cherednychenko, 'The Legal Matrix for Retail Investment Services on the EU: Where Is An Individual Investor?' in Devenney and Kenny (eds, 2012), ch12.

${ }^{160}$ Richard Samuel, 'Tools for Changing Banking Culture: FCA Are You Listening?: Why the FCA's IRHP Mass Dispute Resolution System Has Failed and What the FCA Can Do about It' (2016) 11 CMLJ 129; 'The FCA Has Now Listened: Banks, It Is in Your Interests to Listen Too' (2018) 13 CMLJ 3.

${ }^{161}$ Cherednychenko (2012); Spindler (2011).
} 
This agenda departs from the FCA's recent minimalist attempt to address the consumer investment market. ${ }^{162}$

\section{CONCLUSION}

Paternalistic forms of regulation for the retail investment market have been gradual and restrained, even though significant gaps exist between investors' needs and market-based provision. As ordinary citizens reckon with a variety of savings needs and become financial citizens responsible for their own financial welfare provision, financial health is not merely an issue of individual fortunes but a social need. The need for more regulatory paternalism however goes beyond preventing mis-selling, and the outworking of welfare beyond pointof-sale remains relatively unconsidered. Post-sale welfare is increasingly recognised for consumer credit and is slower to catch on in relation to savings and investments. This article advocates that the regulator should explore increased 'impure' paternalistic options for consumer investor protection, in new duties and responsibilities for investment services providers, as well as enhanced public goods for investor education and protection.

162 FCA, Call for Input (2020). 